\title{
Pelatihan Pembukuan Sederhana pada UMKM Kuliner Di Kelurahan Laweyan Kota Surakarta
}

\author{
Anisa Ferata Ayuning Putri ${ }^{1 *}$, Kartika Hendra Titisari ${ }^{2}$, Widya Putri Ratnasari ${ }^{3}$, \\ Marisa Ayu Nurrohmah ${ }^{4}$, Puji Lestari ${ }^{5}$, Ferlina Ekinanda ${ }^{6}$ \\ Universitas Islam Batik Surakarta, Jl. Agus Salim No.10, Sondakan, Kec. Laweyan, \\ Kota Surakarta, Jawa Tengah 57147,Jurusan/Program Studi Akuntansi, Fakultas \\ Ekonomi. \\ *email: anisaferata12@gmail.com
}

\begin{tabular}{l} 
Informasi Artikel \\
\hline Diterima Redaksi : 2 Desember 2020 \\
Revisi Akhir : 2 Januari 2021
\end{tabular}

Diterbitkan Online : 28 Januari 2021

Kata Kunci:

Pelatihan, UMKM, Pembukuan Sederhana
Abstrak

Di daerah Laweyan terdapat UMKM kuliner yang cukup banyak, namun sangat disayangkan, pelaku UMKM tersebut kurang memperhatikan cara mengelola keuangan dengan baik. Padahal, pada pelaku usaha, laporan keuangan harus diperhatikan dan ditata sebaik mungkin. Pada pengelolaan UMKM, pembukuan sangat penting dilakukan untuk melihat laporan keuangan selama menjalankan usaha. Selain itu, laporan keuangan pembukuan juga dijadikan sebagai patokan untuk membuat strategi kedepannya. Pentingnya melakukan pembukuan, mahasiswa Universitas Islam Batik Surakarta melakukan pembimbingan pembukuan sederhana kepada beberapa pelaku umkm yang ada di Laweyan. Penelitian ini bertujuan untuk menganalisa kendala yang ada di UMKM Laweyan Surakarta, melakukan pembinaan terkait pembukuan sederhana, serta memudahkan pelaku UMKM dalam mengelola laporan keuangan. Metode yang dilakukan adalah dengan cara pendekatan serta pembinaan kepada para pelaku UMKM melalui observasi secara langsung. Adapun hasil dari program yang telah kami lakukan yaitu pelaku UMKM dapat menerapkan ilmu yang telah diberikan, mereka menerima dengan baik program yang kami laksanakan dan juga mereka mulai memahami bahwa mengelola laporan keuangan itu penting.

\section{PENDAHULUAN}

Di lingkungan Kecamatan Laweyan, Kelurahan Laweyanlah yang memiliki jumlah RW paling sedikit yaitu 3 RW dan 10 RT. Walaupun begitu namun kesejahteraan dan gotong royong di masyarakat kelurahan laweyan masihlah sangat terjaga. Kota solo terkenal dengan kerajinan batiknya, ada berbagai macam batik yang terjual di kota solo antara lain batik cap, batik lukis, batik tulis dll. Kelurahan laweyan terkenal dengan sebutan "Kampoeng Batik" karena banyak Pengusaha, Rumah Produksi, Pabrik ataupun Showroom yang berpusat di Kelurahan Laweyan. Tidak hanya usaha batik masih banyak UMKM yang berada dalam lingkungan kelurahan laweyan salah, salah satunya usaha Kuliner. Keberhasilan UMKM menjalankan usahanya tidak terlepas dari kemampuan UMKM mengelola dana. Ketidakmampuan atau kesalahan pengelolaan dana yang dilakukan pemilik meskipun sepele tetapi dapat mengancam keberlangsungan UMKM. Pengelolaan dana yang buruk juga berakibat perusahaan tidak dapat mencegah, mendeteksi maupun mengoreksi tindak kecurangan yang terjadi di perusahaan (Warsono, 2010)

UMKM atau yang lebih dikenal (Usaha Mikro Kecil dan Menengah) 
merupakan suatu pelaku usaha yang memiliki jumlah usaha paling besar. Maka dari itu UMKM termasuk badan usaha yang diatur oleh Undang-Undang No 20 Tahun 2008. Pembukuan adalah transaksi keuangan. Traksaksi tersebut meliputi pembelian, pendapatan dan pengeluaran yang dilakukan oleh perseorangan ataupun organisasi. Dalam usaha kecil seperti UMKM tidak wajar apabila memberi upah seseorang dengan penghasilan tidak pasti disetiap harinya hanya untuk melakukan pencatatan keuangan.

Pencatatan dalam pembukuan sangatlah penting dilakukan oleh para pengusaha kecil maupun besar. Pada umumnya mereka masih sering mengabaikan pencatatan dalam kegiatan bisnis yang dijalani. Dan sebagian dari mereka menganggap pencatatan pembukuan tidak begitu penting karena hasil yang mereka dapatkan tetap dapat memenuhi kebutuhan. Padahal melakukan pencatatan pembukuan keuangan sangatlah penting sehingga para pelaku dapat menentukan strategi bisnis kedepannya. Pembukuan tersebut bisa dilakukan dengan cara yang sangat sederhana, tergantung jenis usaha. Untuk itu pembukuan diperlukan untuk mengetahui transaksi apasaja yang terjadi dalam satu periode, baik uang masuk maupun uang keluar. Serta pencatatannya fleksibel, bisa dilakukan dengan cara otomatis melalui aplikasi atau laptop dan dapat juga dilakukan dengan cara manual dengan menggunakan buku kas.

Kegiatan ini merupakan salah satu cara dalam mahasiswa mengimplementasikan langsung ilmu yang telah mahasiswa dapatkan diperkuliahan, lalu mahasiswa mengajarkan kepada para pelaku UMKM di Kelurahan Laweyan Kota Surakarta. Mahasiswa berharap dalam kegiatan ini dapat sedikit membantu para pelaku usaha dalam melakukan pencatatan pembukuan keuangan yang sederhana.

2. METODE

Kegiatan kepada pengabdian masyarakat di Laweyan Surakarta diselenggarakan pada bulan Oktober-November 2020 .
Adapun metode yang digunakan dalam kegiatan pengabdian pada masyrakat di Laweyan Surakarta, sebagai berikut :

\subsection{Observasi}

Kami melakukan observasi terlebih dahulu pada 20 UMKM kuliner di Laweyan Surakarta. Observasi ini bertujuan untuk mengetahui apa saja kendala pelaku usaha dalam menjalankan usahanya.

2.2 Pelatihan

Memberikan pengetahuan dan informasi kepada UMKM tentang pentingnya pembukuan keuangan bagi keberlangsungan usaha mereka di masa depan.

\subsection{Pendampingan}

Meberikan buku kas dan pelatihan kepada para UMKM guna meningkatkan pemahaman mereka terhadap pembukuan keuangan sederhana

\section{HASIL DAN PEMBAHASAN}

Kegiatan Pengabdian Masyarakat di Laweyan Surakarta selesai dalam waktu 1 bulan, yaitu sejak bulan Oktober hingga bulan November. Adapun pencapaian dalam kegiatan ini antara lain :

a. Dapat menerapkan pembukuan secara sederhana dengan baik dan benar.

b. Membuka mindset mereka mengenai penyusunan laporan keuangan bisnis itu sangat penting.

Kami melakukan observasi untuk melakukan pendataan. Karena adanya Covid 19 mengakibatkan mahasiswi tidak bisa mengumpulkan masyarakat dalam satu tempat. Dalam kegiatan ini terdapat beberapa faktor penghambat yaitu, Susahnya komunikasi dan keterbukaan masyarakat yang mengakibatkan para mahasiswi KKN tidak bisa memberikan solusi terkait permasalahan yang dihadapi UMKM tersebut. 


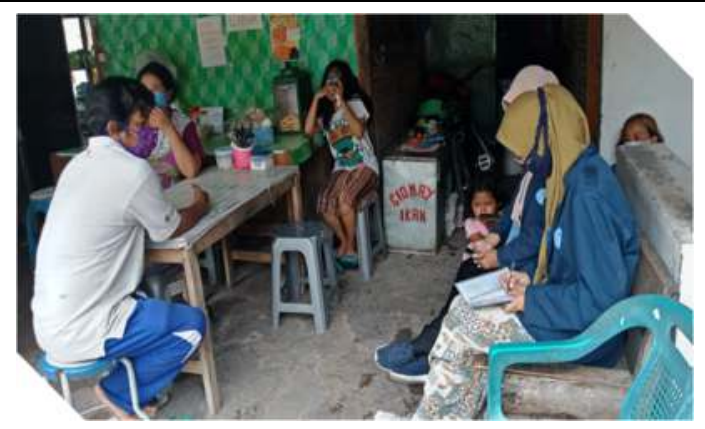

Gambar 1. Observasi

Kegiatan pelatihan dilakukan secara terjadwal, kami menghubungi satu persatu pelaku UMKM agar dapat dilakukan pelatihan. Kebanyakan dari mereka belum melakukan pembukuan sebelumnya. Kendala yang dihadapi yaitu keterbatasan mereka yang tidak melakukan pembukuan dengan baik, dan sebagian dari mereka menganggap bahwa pembukuan itu tidak penting. Lalu kami mengajarkan kepada mereka ilmu yang telah kami dapatkan selama kami belajar dibangku perkuliahan.

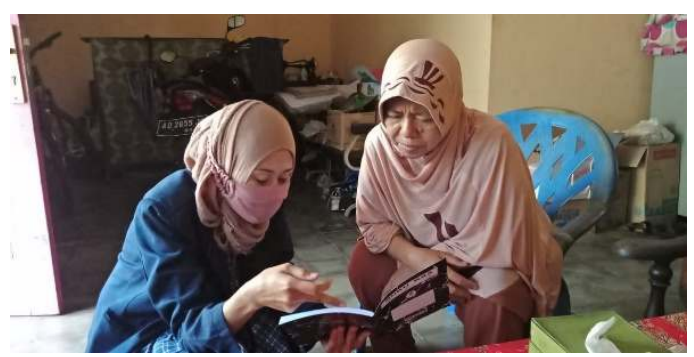

Gambar 2. Pelatihan dan

pendampingan Pencatatan Akuntansi Secara Sederhana.

Pada kegiatan pendampingan kami memberikan buku kas sederhana yang bisa dimanfaatkan dalam menyusun laporan keuangan mereka. Mereka merespon sangat baik ketika kami mengajarkan cara pembukuan sederhana, karena bagi mereka hal ini sangat membantu dalam mengelola keuangan dengan baik. Team Pengabdian Masyarakat melakukan pendampingan awal disaat para pelaku UMKM menyusun laporan keuangan yang telah kami ajarkan dan mereka sedikit demi sedikit mulai memahami cara melakukan pembukuan sederhana.

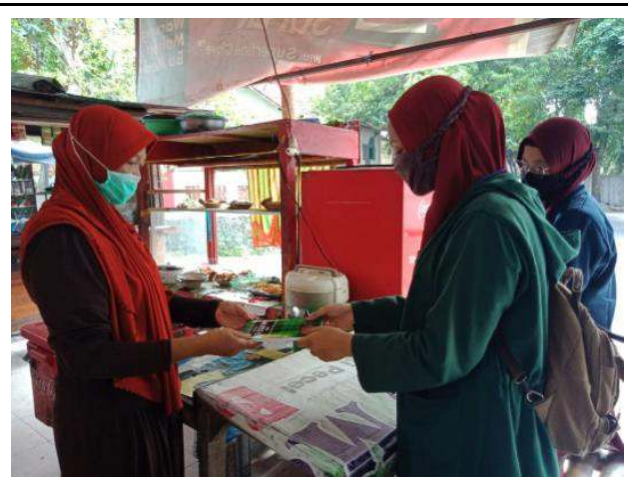

Gambar 3. Pemberian Sarana Pencatatan

\section{KESIMPULAN}

Pada kelurahan Laweyan Surakarta para pelaku UMKM kuliner belum menerapkan pembukuan yang baik dalam usahanya, bahkan sebagian besar dari mereka belum melakukan pembukuan sama sekali. Adapun hal yang membuat mereka enggan untuk menyusun laporan keuangan yaitu usaha mereka berjalan dan menguntungkan bagi para pelaku UMKM. Padahal membuat pembukuan sangatlah penting bagi pelaku bisnis.

Dengan adanya kegiatan pengabdian kepada masyarakat yang dilakukan oleh team KKN Universitas Islam Batik Surakarta dapat memberikan manfaat, ilmu pengetahuan serta membuat para pelaku usaha untuk lebih memperhatikan lagi dalam pembuatan laporan keuangan bisnis mereka. Sehingga keuangan mereka dapat terkelola dengan baik.

\section{SARAN}

Adapun yang menjadi saran penulis yaitu dalam mewujudkan peningkatan perekonomian di Indonesia peran UMKM sangat penting sehingga memerlukan dukungan terutama dari pemerintah. Dengan dukungan dari pemerintah (entah itu dalam bentuk bantuan, fasilitas, d.1.1) maka perekonomian Indonesia akan meningkat.

Saran penulis kepada pembimbing adalah diperlukannya edukasi kepada para pelaku usaha mengenai pentingnya pembukuan. 


\section{UCAPAN TERIMA KASIH}

Terimakasih kepada kepala program studi akuntansi, kepada dekan fakultas ekonomi yang telah menyetujui pelaksanaan pengabdian kepada masyarakat. Terimakasih untuk pihak kelurahan laweyan surakarta atas persetujuan kegiatan pengabdian kepada masyarakat. Ucapan terimakasih yang terakhir adalah kepada teman-teman mahasiswa program studi ekonomi akuntansi universitas islam batik surakarta yang telah berbagi ilmu dan pengetahuan kepada masyarakat.

\section{REFERENSI}

[1] Agustina, Yumniati, Setianingsih, Sri and Santoso, Yudy Dwi. 2019. Pelatihan Penyusunan Laporan Keuangan Bagi Entitas Mikro, Kecil, dan Menengah Bidang Usaha Dagang pada UMKM Binaan Pusat Inkubasi Bisnis Syariah Majelis Ulama Indonesia. April-September, 2019, Vols. 1, No 1, http://ojs.itbad.ac.id/index.php/IK.

[2] Laily, Nur, Sidharta, Yudi and Efendi, David. 2019. Pelatihan Pembukuan Sederhana Bagi Wanita Wirausaha Batik Jonegoro Kabupaten Bojonegoro. 2019, Vols. 03, No 01. 43-46, Jurnal Layanan Maasyarakat Universitas Airlangga.

[3] Machfuzhoh, Asih, Kutfi and Utami, Ika. 2020. Pelatihan Pembukuan Sederhana Bagi UMKM Menuju Naik Kelas Di Kecamatan Grogol. 2020, Vols. 1, No 2. 109116 , http://ejournal.umm.ac.id/index.php/j anayu.

[4] Margunani, Melati, Sari Inaya and Sehabuddin, Ahmad. 2019. Pelatihan Pencatatan Keuangan Sederhana UMKM Intip di Desa Nyatnyoyo Ungaran Semarang. 2019, Vol. 4 , 3. http://journal.unhas.ac.id/index.php/p anritaabdi.
[5] Mulyanti, Dwinta and Nurdin, Sahidillah. 2018. Pelatihan Perencanaan Keuangan Keluarga Bagi Ibu-Ibu PKK Desa Cimenyan Kabupaten Bandung. Agustus, 2018, Vols. 1, No 2. 259-267, http://ejournal.bsi.ac.id/ejurnal/index. php/abdimas.

[6] Ningrum, Endah Prawesti, et al. 2019. Pelatihan Pembukuan Sederhana,Sosialisasi Perpajakan dan Pengelolaan Manajemen Bagi UMKM Ibu-Ibu Catering Perumahan Jatimulya RW.012. 2019, Vols. 2, No 2,126-130,

http://jurnal.ubharajaya.ac.id/index.p hp/jabdimas.

[7] Sari, Tunggal Cahyani and Indriani, Etty. 2017. Pentingnya Pembukuan Sederhana Bagi Kelompok UMKM KUB Murakabi Desa Ngargoyoso. 2017, Vols. 1, No 1, Wasana Nyata (Jurnal Pengabdian Pada Masyarakat).

[8] Wahyuningsih, Dwi Endang, Setiawati, Ira and Prasojo, Adi Teguh. 2017. Pemberdayaan Pelaku Usaha Mikro Dengan Memberikan Pelatihan Pembukuan Sederhana Di Desa Bangunrejo Kecamatan Patebon Kabupaten Kendal. 2017, Prosiding Seminar Nasional Publikasi HasilHasil Penelitian dan Pengabdian Masyarakat. 